\title{
ANÁFORA E CORREFERÊNCIA: POR QUE AS DUAS NOÇÕES NÃO SE IDENTIFICAM?
}

\author{
RODOLFO ILARI \\ UNICAMP
}

RÉSUMÉ: Dans cet article je soutiens que l'anaphore textuelle et la co-référence sont deux phénomènes imbriqués mais distincts, si bien que le cas où une expression anaphorique s' interprète strictement comme la récupération d'un référent présenté préalablement dans le même texte n'est ni le seul possible, ni le plus instructif. Pour le montrer, je me rapporte à un concepte célebre dans la littérature sur la référence - celui de singular term, que Zeno Vendler exposait naguère dans Linguistics and Philosophy (1967), et je montre à propos d'un certain nombre d'extraits de journaux brésiliens récents qu'il peut y avoir anaphore entre deux syntagmes nominaux du même texte même si ces syntagmes ne peuvent pas être analysés comme des singular terms d' après les critères de Vendler. Ces exemples montrent que si l'on veut malgré tout donner une explication référentielle de l'anaphore textuelle, on doit payer le prix d'un élargissement considérable du concept de référence. On a alors intérêt à le rédéfinir dans le cadre des représentations réciproques des interlocuteurs et de leurs ressources cognitives, ce qui finit par ramener l'anaphore au domaine des contraintes et des faits traditionellement reconnus comme pragmatiques.

A crença de que o fundamento da anáfora é uma operação semântica de correferência esteve presente nos últimos anos em muitos estudos realizados sobre o assunto, orientando as investigações não só de lingüistas que estudaram a anáfora como fenômeno intra-sentencial, mas ainda de outros que pretendiam tratar de coesão textual, e, portanto, se predispunham a priorizar relações cujo domínio é, por definição, mais amplo do que a estrutura sintática da sentença.

Em um trabalho anterior ${ }^{1}$, lembrei que essa crença já foi objeto de formulações muito radicais, e citei como exemplo uma passagem da lingüista soviética Anna Padučeva em que o fato de dois nomes serem correferentes era dado como condição

\footnotetext{
${ }^{1}$ Trata-se de um trabalho que apresentei em 2000, em Curitiba, num encontro do Celsul, durante uma mesa redonda que contou com a participação de Luiz Antônio Marcuschi (UFPe) e Ana Lúcia de Paula Müller (USP) e que foi inteiramente dedicada ao tema da anáfora. O presente trabalho é, em grande parte, uma versão reformulada daquele. Agradeço os organizadores daquele evento por me proporcionaram aquela oportunidade. Agradeço também a Profa. Ingedore Koch, pelo estímulo a retomar aquele texto. A presente versão é ainda problemática, mas menos descabelada.
} 
necessária e suficiente para considerá-los em relação de anáfora ${ }^{2}$; mostrei também que essa mesma concepção de anáfora serviu de fundamento para a elaboração de um modelo de discurso narrativo ${ }^{3}$ que pode ser encarado como uma aplicação aos textos narrativos de alguns dos procedimentos de interpretação utilizados pelas lógicas elementares, em particular a separação no universo de discurso de um conjunto de indivíduos e de um conjunto de relações, e procurei argumentar que essa concepção da narrativa, embora esclareça alguns aspectos não óbvios de certos tipos de textos, não consegue dar conta de um grande número de relações coesivo-textuais que reconhecemos intuitivamente como anafóricas.

Minha posição era, em suma, que a linha de reflexão que tira partido da noção de correferência, à primeira vista mais óbvia, leva a uma explicação reducionista. Trata-se de uma posição paradoxal, que, naquele trabalho, procurei basear nos seguintes argumentos:

1) os textos que efetivamente usamos no dia-a-dia, mesmo quando falam de realidades bastante familiares, dificilmente organizam essas realidades como ontologias compostas de objetos discretos entre os quais se estabelecem relações claramente sujeitas ao princípio do terceiro excluído. Imaginemos um texto de história contemporânea como os que apareceriam nos livros didáticos: é pouco provável hoje que ele tome a forma de uma narrativa cujos protagonistas são apenas pessoas. O normal é, ao contrário, que ele tenha como protagonistas instituições sociais (como o Estado Novo) ou entidades coletivas (como o operariado dos anos 30); é esperado também que um texto desses faça referência a produtos culturais (como a censura), a épocas, momentos, datas e situações. É comum a referência a acontecimentos pontuais (como a prisão de Graciliano Ramos) ou reiterados (como a transmissão diária da Voz do Brasil) ou a processos mais ou menos complexos (por exemplo, o controle exercido sobre os intelectuais). É pelo menos forçado querer reduzir todos esses possíveis "objetos de referência" à noção de objeto com que se trabalha nos modelos lógicos mais elementares. Vários desenvolvimentos da semântica lingüística (por exemplo, os que levaram à incorporação da noção de evento) mostram de resto que a semântica formal não é insensível a essa diversidade.

2) Nos textos de que nos valemos no dia-a-dia, não só é comum que se faça um uso polissêmico das palavras (por exemplo, um livro pode ser qualificado sucessivamente como encadernado - o que remete ao objeto físico ou a um tipo de edição, ou como difícil - o que remete mais provavelmente a seu conteúdo, ou como difícil de achar, o que pode ser ambíguo) mas ainda é normal que aspectos distintos de uma mesma realidade sejam tratados ora como iguais ora como distintos. Para ilustrar esse fato, usei naquele texto um trecho de uma aula sobre Cinema Brasileiro ministrada na Universidade de S.Paulo na década de 60 e recolhida como inquérito do Projeto

\footnotetext{
2 "The relation between two names of a given text that have identical denotata may be called anaphoric relation" in Paduceva, A. (1970), "Anaphoric Relations and Their Representation in the Deep Structure of a Text". in Bierwisch \& Heidolph, Progress in Linguistics. Haia, Mouton.p.226

${ }^{3}$ Exposto em Bonomi (1994) Lo spirito della narrazione. Milão: Bompiani.
} 
NURC. Mostrei que o "objeto" "cinema brasileiro dos anos 30" era apresentado, na seqüência do texto, sob aspectos que não deixam de ser "cinema brasileiro dos anos 30", mas que têm características distintas e às vezes contraditórias: os "filminhos" nacionais, o comércio cinematográfico baseado na importação, os donos de salas de espetáculo, os produtores, etc. A referência interpolada a essas diferentes realidades confere ao texto uma poderosa estruturação anafórica, mas esses diferentes "cinemas brasileiros" são portadores de características contraditórias e por isso têm que ser tratados como coisas diferentes (por exemplo: ser marginal e artesanal é uma tendência do cinema nacional da década de 30 , aliás compartilhada com outras épocas; tornar-se indústria é uma característica do cinema que o Brasil começou a importar naquele período, não do cinema autenticamente brasileiro; passar por uma situação de caos no começo dos anos 30 é uma vicissitude do cinema importado, decorrente do advento do cinema falado, e não do cinema autenticamente nacional; prosperar na década de 30 apesar de seu caráter artesanal é uma vicissitude do cinema brasileiro e não do comércio cinematográfico baseado na importação). Quem quisesse explicar as várias remissões anafóricas presentes num texto assim construído em termos de correferência estrita acabaria chegando à conclusão de que o texto - que em algum sentido fala sempre de cinema brasileiro - é altamente contraditório; o que não é o caso.

3. Se pensarmos a anáfora como correferência, e a correferência como uma relação que se estabelece entre expressões que remetem a objetos, torna-se impossível tratar de relações anafóricas em que o antecedente é um predicado, ou uma oração, ou mesmo uma porção mais ou menos determinada de um texto. Suponhamos que alguém acaba de narrar como sobreviveu a um desastre de grande proporções e acrescente, a título de comentário, (1) ou (2):

(1) isso foi um milagre

(2) depois dessa, eu acho que nasci de novo

O antecedente do pronome isso será mais provavelmente o predicado de uma das últimas sentenças pronunciadas, ou uma sentença toda, ou mesmo um trecho relevante da narrativa que precede. Há na gramática de toda língua uma tendência a especializar expressões para a tarefa de retomar anaforicamente conteúdos de natureza sentencial. Em português, algumas expressões que sofreram essa especialização são precisamente os demonstrativos isso e essa, que têm nesse emprego um uso bem mais extenso do que os dêiticos homônimos. Outros anafóricos para conteúdos de sentenças podem ser procurados entre as expressões que a gramática classifica como advérbios e conjunções, ou entre os circunstanciais: então, portanto, entretanto, por conseguinte, nessas condições, guardam, em muitos de seus empregos, um evidente valor de anáfora em relação à sentença anterior. Para essas palavras e expressões, a descrição gramatical que as qualifica como conjunções, advérbios, "circunstanciais" ou mesmo "demonstrativos neutros" é insuficiente. Uma boa descrição precisará associar-lhes a função de retomar anaforicamente conteúdos que o texto apresentou previamente na forma de sentenças ou de seqüências de sentenças; como esses contéudos não são objetos, mas sim relatos de 
fatos ou de estados de coisas, a noção de correferência, atrelada historicamente à noção de objeto, acaba fazendo injustiça às nossas intuições e obstrui a descrição gramatical.

Para fundamentar a tese de que assimilar anáfora e correferência é um equívoco, meu texto de 2000 utilizava, além dos três argumentos que acabo de resumir, um quarto argumento que ficou apenas esboçado: o sentido geral desse argumento é que pode haver anáfora entre expressões nominais mesmo quando essas expressões não são referenciais e, reciprocamente, que é possível haver correferência entre sintagmas nominais que aparecem em pontos diferentes de um mesmo texto, sem que haja anáfora. Esse argumento é mais forte do que os anteriores, porque se refere a sintagmas nominais, isto é, a expressões gramaticalmente apropriadas para falar de objetos e coleções de objetos. Na seqüência deste texto, eu pretendo expor esse argumento com alguma sistematicidade, lançando mão de exemplos extraídos de um corpus de textos de jornais publicados entre 2000 e 2001 que venho organizando. Provavelmente, os textos que selecionei e sua análise (que foi altamente problemática e por isso mesmo tende a ser provocativa) são a parte mais interessante do presente trabalho, mas eles não serão apresentados de imediato. Como se sabe, a própria noção de referência é, em si mesma, problemática. Para contornar essa dificuldade, resolvi dedicar a próxima seção à exposição da concepção de referência em que me basearei em seguida, que é derivada do capítulo "Singular Terms" de Vendler (1967). Tentei ser breve nessa resenha, que ocupa toda a seção 2. Mas o leitor que já conhece bem Vendler não precisará ler uma resenha à qual falta o charme do texto original e que nem sempre faz um uso ortodoxo das idéias daquele autor. A recomendação que faço a esse leitor é que pule diretamente para a seção 3 .

2. As razões pelas quais me reporto ao texto de Vendler no momento em que procuro estabelecer o uso que será feito das palavras "referir" e "referência", nas seções seguintes deste trabalho, vão além do fato de tratar-se de um texto "che mi piace" e que foi reeditado em uma antologia de grande circulação ${ }^{4}$, o que o torna bastante acessível; sua escolha prende-se ao fato de que ele descreve - pela primeira vez na bibliografia que eu conheço - o que poderíamos chamar de uma "cadeia de expressões correferenciais". Mas atenção: esse termo não foi usado por Vendler, que fala em vez disso em "cadeias de identificação"; de resto, no texto em questão, Vendler não está interessado em tratar de problemas de coesão textual (seria estranho que um filósofo o fizesse), mas sim em mostrar como os falantes se apoiam em sua competência lingüística na realização de uma tarefa cujo interesse é eminentemente lógico: determinar se os sintagmas nominais que intervêm num texto (argumentativo ou outro) devem ou não ser interpretados como "termos singulares".

\footnotetext{
${ }^{4} \mathrm{O}$ texto em questão foi publicado como capítulo do livro Linguistics and Philosophy, de autoria do próprio Vendler (Ithaca: Cornell University Press, 1967, pp.33-69). Foi também incluído na conhecida antologia de Steinberg e Jakobovitz (1971) Semantics, an Interdisciplinary Reader in Philosophy, Linguistics and Psychology (Cambridge Univeristy Press, - pp. 115-133).
} 
Para facilitar a compreensão do que Vendler se propõe como problema, transcrevo aqui um dos tantos exemplos que ele analisa: ${ }^{5}$

(3) Mary is a demanding girl. The man she loves must be generous.

(4) Mary loves a man. The man she loves must be generous.

(5) Mary loves a man. The man must be generous.

O que está em questão nesses três exemplos é a interpretação do sintagma nominal the man. Segundo Vendler, the man é inequivocamente um termo singular em (5), é mais provavelmente - mas não necessariamente - um termo singular em (4), e é mais provavelmente (mas não necessariamente) um termo geral em (3). Percebe-se, por esses exemplos, e pela terminologia que Vendler usa para analisá-los ("termos singulares" $\times$ "termos gerais") que Vendler, quando fala em "termos singulares", não está interessado na oposição morfológica entre singular e plural, nem nos seus correlatos semânticos. Termo singular, em oposição a termo geral, é aquele que consegue "identificar" um determinado indivíduo. Quem fala em "identificar" é o próprio Vendler, mas provavelmente essa palavra é forte demais. Para uma identificação ideal, exige-se normalmente que saibamos dar informações bastante exatas sobre uma a pessoa ou coisa identificada. O discurso (5) continua compreensível, e the man mantém seu status de termo singular mesmo que tenhamos como única certeza sobre o indivíduo que ele denota que ele é amado por Mary. Assim, seria talvez mais exato falar em "pinçar", "selecionar" alguma pessoa ou coisa dentro de um conjunto. E isso nos leva direto a uma bibliografia em que se fala de referência - um termo que, ao que tudo indica, Vendler quis evitar. Sem que nos envolvamos em discussões terminológicas, penso em todo caso que a distinção entre as duas interpretações possíveis para the man é fácil de ser captada intuitivamente: trata-se, num caso, de falar de uma pessoa específica, no outro de falar de todos os amados de Mary. No primeiro caso, the man (she loves) é um termo singular, no outro é um termo geral.

A expressão que Vendler destaca para análise nos exemplos (3)-(5) é, na terminologia dos lógicos, uma descrição definida, ou seja, um sintagma nominal que começa com um artigo definido e continua com substantivo comum que atribui determinadas propriedades a seu(s) referente(s). Vendler tem idéias muito precisas sobre o que justifica a presença do artigo definido nessas sentenças: segundo ele, o artigo definido é sempre a marca linguística explícita de que uma operação de restrição foi realizada, e o mecanismo standard para realizar restrições é o uso de orações relativas (eventualmente reduzidas a um adjetivo ou a um adjunto). Assim, a presença do artigo definido é sempre explicada por Vendler como o correlato visível de uma oração relativa que pode aparecer explicitamente (como em (3) e (4)), mas que também pode estar implícita; este segundo caso é ilustrado por (5) onde, segundo Vendler, a oração relativa não aparece explicitamente porque pode ser recuperada a partir do contexto anterior, caso em que sua ocorrência seria redundante. $\mathrm{O}$ artigo definido teria, além do mais, a função de indicar que, uma vez efetuada a operação de restrição

\footnotetext{
5 exemplos (24), (25), (26), p.54 de Linguistics in Philosophy, citado.
} 
indicada pela oração relativa, o conjunto resultante é considerado de maneira exaustiva (o único amado de Mary, todos os amados de Mary, conforme o número gramatical é ou não o plural).

Uma pergunta que se coloca é o como funciona o processo de recuperar informações a partir do contexto anterior, transformando-as no conteúdo de uma oração relativa, e quando essa oração relativa pode ser considerada redundante e por conseguinte omitida. A resposta de Vendler considera vários aspectos da questão, e por isso se desdobra numa série de considerações que têm em comum a preocupação de fundamentar-se numa análise tão exata quanto possível do contexto lingüístico:

1) a oração relativa que funciona como contraparte do artigo definido e a oração que ela recupera do contexto anterior precisam compartilhar um sintagma nominal. Isso não acontece em (3), do que resulta que, nessa sentença, the man she loves terá de preferência uma leitura generalizante;

2) não conta a função sintática que o sintagma nominal compartilhado desempenhava no contexto anterior (essa função é a de objeto direto em "They dug a hole with a stick. The stick, etc." / é de sujeito em "A boy had dinner with me. The boy...").

3) Conta, ao contrário que, no texto que precede, o sintagma nominal compartilhado se relacione com outro termo singular num contexto não copulativo e não modal.

Esta última condição dá conta da falta de continuidade que percebemos intuitivamente em sequências como (7) e (8), e do fato de que em (9) e (10) pode haver ou não continuidade.

(1) (?) Ele é um príncipe. O príncipe é preguiçoso

(2) (?) Ele se tornou caixeiro-viajante. O caixeiro-viajante é bem pago.

(3) João seria capaz de levantar um touro. O touro é pesado

(4) Você precisa comprar uma casa. A casa tem quatro quartos

Ao refazer o caminho que convida a recuperar um sintagma nominal presente numa oração anterior, chegamos facilmente a visualizar aquilo que eu chamei mais acima de "cadeia de expressões correferenciais" (e que Vendler chama de "cadeias de identificação" ). Analisando sentenças sucessivas de um mesmo texto, percebemos que o caráter singular dos termos presentes nas primeiras orações se transfere (com a condição de que o verbo seja não copulativo e não modal) aos novos termos que elas vão introduzindo, e é conservado nas orações seguintes. É assim que se chega a um mecanismo de coesão que, por ser mais facilmente visualizado nas fábulas, em narrativas como

(5) [Era uma vez um rei. $]_{S 1}[\mathrm{O} \text { rei tinha uma filha. }]_{\mathrm{S} 2}$ [A filha gostava de um príncipe.... $]_{\mathrm{S} 3}$ 
eu chamei no passado de "modelo dos contos de fadas" ; no exemplo, um rei $i_{\mathrm{S1}}$ "se identifica" com o rei $i_{\mathrm{S} 2}$; essa expressão ganha assim o status de termo singular, e essa propriedade é, por assim dizer, "transmitida" pelo verbo tinha a uma filha $a_{\mathrm{S} 2}$. Aí o processo recomeça: uma filha $a_{\mathrm{S} 2}$ se identifica por sua vez com a filha $a_{\mathrm{S} 3}$ que, através do verbo gostava confere seu caráter de termo singular a um príncipe $_{\mathrm{S} 3}$, e assim sucessivamente.

Para sermos exatos, o que acabo de descrever aqui não é exatamente uma cadeia, e sim um processo de encadeamento: em outras palavras, supondo que tenha ficado claro que o caráter singular de um termo presente na oração anterior se transfere a outros usos do mesmo termo feitos numa oração seguinte, e supondo, além disso, que tenha ficado claro que esse processo pode ser reiterado "ad infinitum", nada foi dito sobre o modo como ele começa.

A idéia de Vendler é que, no começo de toda cadeia, breve ou longa que seja, encontraremos sempre um "termo singular primitivo", e por "termo singular primitivo" ele entende os nomes próprios e os pronomes dêiticos como $e u$ e $t u$. A atribuição desse caráter aos pronomes e aos nomes próprios é apoiada numa série de testes distribucionais, envolvendo, mais uma vez, as orações relativas (Vendler mostra que muitas formas de relativização são incompatíveis com palavras desse tipo e que, quando o são, resultam em orações relativas apositivas, não restritivas).

Feita em poucos parágrafos, a apresentação do texto de Vendler que precede, é extremamente esquemática, e retém do original apenas o essencial para a discussão que vai seguir. Ela deixa de lado muitas ressalvas que o próprio autor faz a propósito de suas próprias teses, e muitos convites a investigar mais a fundo várias questões que constituem autênticos quebra-cabeças tanto para os lingüistas como para os filósofos. Como essa apresentação servirá de pano de fundo a uma discussão da noção de cadeias referenciais, convém lembrar que Vendler vislumbrou a possibilidade de que haja cadeias de outro tipo, além daquelas em que se preserva o caráter "identificador" dos termos, e que numa sequiência como (11) há continuidade, embora a casa em questão não pertença necessariamente ao mundo real.

\section{(11) I dreamt about a house. The house...}

Mas num balanço final a idéia de continuidade se aplica de preferência aos casos em que se preserva a identificação de um objeto que é único entre outros de sua espécie e passível de ser localizado no mundo real.

Por essas características, e pela importância dada ao verbo que introduz a primeira ocorrência do termo, o texto de Vendler acaba lembrando uma famosa distinção de Quine, para quem as ocorrências de descrições definidas não podem ser referenciais (extensionais) quando estão incluídas no escopo de um operador que cria contextos opacos - como é o caso dos operadores que exprimem modalidade, atitude proposicional (crença, desejo, etc.) ou mesmo dos operadores que levam a considerar a forma soletrada das palavras. Alguns célebres exemplos de Quine são: 
(12) Giorgione era assim chamado [ou seja, era chamado "Giorgione"] por ser grandão e meio desengonçado

(13) João está caçando um jacaré de papo amarelo [ou seja quer capturar jacaré de papo amarelo].

Há duas maneiras de entender essa sentença, correspondentes às fórmulas:

a. Existe $\mathrm{x}$ tal que $\mathrm{x}$ é jacaré de papo amarelo e João quer (João captura $\mathrm{x}$ )

b. João quer (existe $\mathrm{x}$ tal que x é um jacaré de papo amarelo e João captura x)

O tipo de continuidade mais amplamente discutido por Vendler não seria possível para uma ocorrência de "Giorgione" entre aspas (Não seria possível acrescentar a (12) "ele era uma palavra de nove letras"), nem seria possível no caso da segunda leitura (b.) de "um jacaré de papo amarelo" (De fato não é possível acrescentar a (13) "Ele matou 3 pescadores e João acabará por encontrá-lo" sem passar imediatamente para a leitura (a.). Mas faríamos uma enorme injustiça à acuidade lingüística (não só filosófica) das análises de Vendler se não lembrássemos que, de passagem, ele aponta para a possibilidade de continuarmos discursos como (13) na interpretação (a.) usando em vez do pronome pessoal $\underline{\mathrm{o} / \mathrm{lo}}$ o pronome indefinido $\underline{\mathrm{um}}, \mathrm{cp}$.

(14) João está procurando um jacaré de papo amarelo no Rio Tietê. Com alguma sorte, acabará por achar um.

3. Podemos, finalmente, passar à seção de análise deste trabalho. Os textos que serão analisados a seguir foram extraídos de notícias de jornais publicadas nos últimos anos. São portanto exemplos de língua escrita padrão, com grau médio de formalidade. De acordo com a função que desempenham neste trabalho, eles podem ser divididos em dois conjuntos. O primeiro conjunto, ao qual é dedicada a seção 3.1. compõe-se de exemplos destinados a mostrar que a ambigüidade entre uma leitura "singular" e uma leitura "genérica" das descrições definidas, principal tema de Vendler, marca presença nos textos, e recebe, freqüentemente, uma solução textual. Os exemplos do outro conjunto (dos quais trato em 3.3.) têm em comum a seguinte característica: em todos eles é possível perceber algum tipo de continuidade, que chamaríamos de bom grado "anafórica", mas nenhum deles é uma "cadeia de identificação" no sentido de Vendler. Trata-se então de cadeias de algum outro tipo, e é relevante entender o que leva a reconhecê-las como tais é relevante para explicar a anáfora em termos semânticos. Nas seções 3.2. e 3.4. tento formular algumas generalizações sugeridas pelas análises realizadas nas seções imediatamente anteriores.

3.1. O primeiro texto que analisarei aqui foi publicado há alguns anos numa página interna da Folha de São Paulo, e trata de uma estratégia de vendas cada vez mais usada nos supermercados - a que consiste em juntar num mesmo espaço produtos de procedência diferente (digamos, a carne para churrasco, que provém do pasto através 
do frigorífico, o sal grosso que provém do mar, e os espetos, produto da indústria siderúrgica leve) quando, na perspectiva do comprador, fazem parte de um mesmo "script" (no caso o churrasco domingueiro). A primeira particularidade a notar nesse texto é uma ambigüidade de sua manchete, "Produto troca de prateleira e vendas crescem" que tem a ver com a ausência de artigos, um fenômeno comum nas manchetes de jornais. No primeiro momento, quem lê esse título não tem como decidir se a matéria jornalística falará de um produto determinado que, mudando de prateleira, se tornou mais vendável, ou enuncia uma espécie de lei geral da mercadologia moderna. As palavras "produto", "prateleira" e "vendas", tais como são usadas no título, ficam abertas, em outras palavras, tanto a uma leitura específica, como a uma leitura generalizante.

Produto troca de prateleira e vendas crescem - "Em pesquisa realizada pela Universidade de São Paulo em três grandes supermercados da capital, ficou provado que expor o produto perto de outros gêneros com que combina é uma maneira de aumentar as vendas. Os exemplos mais impressionantes foram, nesse sentido, o carvão e o sal para churrasco: habitualmente, o carvão para churrasco é vendido junto aos detergentes, e o sal para churrasco junto aos demais temperos. Num dos supermercados que foram objeto de estudo, os pesquisadores da Universidade de São Paulo deslocaram cem pacotes de carvão $\underline{e}$ cem pacotes de sal para junto das gôndolas do açougue, e verificaram que esses pacotes foram vendidos num tempo $20 \%$ menor. Há uma explicação, diz João Paixão Neto, gerente da loja do Pão de Açúcar da Alameda Santos: o supermercado vende a mesma carne, o mesmo sal e o mesmo carvão; mas o cliente compra, em bloco, a idéia de um suculento churrasco, $e$ com isso regateia menos".

Uma vez constatada essa dupla possibilidade de interpretação, há pelo menos duas observações a fazer: a primeira é que, independentemente da interpretação que o leitor do jornal escolhe para o título, nós sabemos que as vendas que aumentam são as do produto (ou produtos) que mudou (ou mudaram) de prateleira. Penso que essa é uma boa razão para entender que "vendas" é anafórico de "produto", e isso nos alerta por sua vez para um fato cada vez mais freqüente nos textos escritos (e generalizado nos textos falados): é possível anaforizar omitindo o anafórico. Essa possibilidade se manifesta de várias maneiras, que em sua maioria envolvem o uso de expressões relacionais, sejam elas predicados de dois lugares (inclusive predicados comparativos), expressões que identificam papéis temáticos, expressões que indicam o nexo entre dois conteúdos proposicionais, ou outras. Eis alguns exemplos breves:

(15) Um cachorro foi atropelado na Av. Samuel Martins. $\underline{\text { O dono saiu de revólver atrás }}$ do motorista.

(o dono $=\mathrm{o}$ dono daquele cachorro $)$

(16) Um cachorro foi atropelado na Av. Samuel Martins. Por muito menos já houve mortes na Vila Cristo

(por muito menos = por muito menos do que um atropelamento de cachorro, ou por muito menos do que o atropelamento daquele cachorro, etc.) 
(17) Um cachorro foi atropelado na Av. Samuel Martins. O motivo é que a prefeitura retirou as lombadas

(a retirada das lombadas foi motivo do atropelamento do cachorro)

Há muita coisa a explicar, a propósito desses casos de anáfora em que o anafórico sumiu: por exemplo, sabemos pouco sobre o que distingue a omissão do anafórico da elipse, e o fato de que ninguém se atrapalha nesses casos é um paradoxo, ou talvez um milagre, como lembra, oportunamente, o Prof. Luiz Antônio Marcuschi.

Mas voltemos à questão da ambigüidade da manchete que, sem prejuízo de conter uma anáfora, poderia ser interpretada como expressando uma lei geral ou como falando de um produto determinado. Parece-me razoável admitir que essa ambigüidade se desfaz no texto da notícia quando percebemos que a história do carvão e do sal de churrasco, que tiveram suas vendas aumentadas depois que passaram a ser expostos perto do açougue é dada explicitamente como um dos tantos exemplos possíveis (cp. "Os exemplos mais impressionantes foram, nesse sentido, o carvão e o sal para churrasco") de uma lei geral ("expor o produto perto de outros gêneros com que combina é uma maneira de aumentar as vendas". Que se trata de uma lei, fica evidente pelo fato de que a última sentença que acabo de transcrever em itálico, aliás introduzida como subordinada de "ficou provado", está no presente atemporal). Este é bem um caso em que a ambigüidade entre uma leitura "singular" e uma leitura "genérica" de um sintagma nominal definido marca presença e recebe uma solução textual. O leitor poderia pensar que essa ambigüidade se manifesta somente nos títulos de jornais, mas não é verdade, como mostrarei nos exemplos a seguir.

Seja como for, antes de passar a outros exemplos, convém fazer mais uma observação. A título de exercício, pensemos para aquela manchete uma terceira interpretação (diferente das duas que consideramos até aqui), segundo a qual a mudança de um produto específico teria afetado as vendas em geral (imaginemos, por exemplo, que a notícia se refere ao fato de que o supermercado recuou para uma gôndola pouco visível as camisas da Mancha Verde, que isso fez com que toda a torcida do Corinthians, majoritária na região, passasse a comprar em peso naquele estabelecimento). Quando a interpretação é essa (com quantificação específica em produto e genérica em vendas), o fato a notar é que a anáfora do título desaparece. Isso poderia estar mostrando que é mais fácil haver anáfora entre expressões que são quantificadas do mesmo modo, ou, por outra, que a anáfora tende a preservar a quantificação do antecedente, a menos que todo um trabalho lingüístico suplementar seja feito para permitir o contrário. Isso leva a duas perguntas, que identificam duas linhas de reflexão bastante promissoras:

1) o que significa "preservar a quantificação do antecedente"?

2) que tipo de "trabalho lingüístico" é necessário para que possa haver "preservação ou mudança de quantificação" numa relação anafórica?

Para responder à primeira pergunta, será preciso aplicar no âmbito das relações inter-sentenciais os conhecimentos que a investigação semântica das últimas décadas 
acumulou sobre quantificação nominal e sobre as conexões que ela mantém com vários tipos de predicação. Os contornos desta linha de investigação não são claros, mas isso parece dever-se antes a um desconhecimento recíproco entre os semanticistas (que têm trabalhado sobretudo no nível intra-sentencial) e os especialistas em lingüística textual, do que a um problema de princípio. Sobre a segunda pergunta, o máximo que posso fazer por ora é sugerir que os mecanismos que "preservam" a quantificação e os que a "alteram" devem ser analisados numa perspectiva de continuidade: possivelmente, eles mobilizam as mesmas categorias semânticas. Para ter uma idéia do que é o "trabalho lingüístico" que torna viáveis as mudanças de quantificação, veja-se o que acontece na matéria do jornal entre a afirmação genérica de que expor o produto perto de outros gêneros com que combina é uma maneira de aumentar as vendas e o relato do que aconteceu com os cem pacotes de carvão e cem pacotes de sal que, colocados junto das gôndolas do açougue, venderam num tempo $20 \%$ menor. O sal e o carvão, que eram inicialmente apresentados como substâncias, são "transformados" lingüisticamente em pacotes, e além disso a escolha do local de exposição da mercadoria mudou de enquadramento aspectual: do habitual (iterativo) para o pontual (semelfactivo). Mas tudo isso parece ser apenas a ponta de um grande iceberg da gramática da coesão.

Considere-se agora este segundo texto, publicado há alguns meses na página de esporte da Folha de São Paulo:

\section{Disneylândia no inferno.}

"Aos 16 anos, James Michael Moriarty remou para o outside em um Maverick's (EUA) gigante. Era 21 de dezembro de 1994, dia mais tarde batizado de Big Monday. Remou para sua primeira onda, e, quando resolveu desistir de surfá-la, era tarde".

"Fiquei em pé, olhei para baixo, e vi nada a não ser ar, 35 pés de vazio. Tive uma fração de segundo para pensar 'Oh, m...' quando a prancha voou contra meu corpo e o lip me pegou pelas costas".

O impacto foi terrivel: fui socado contra o fundo numa terrível turbulência. Tentei me concentrar em ficar relaxado. Fui rolando e sacudindo, e tive sorte de encontrar o fundo com os pés. Demorei muito para subir. Mantive meus olhos abertos e tudo estava preto.

Sabia que, se não subisse logo, a próxima onda estaria sobre mim; então nadei o mais rápido possível que pude para poder respirar. A segunda onda não foi tão ruim quanto a primeira, mas me rolou um bocado"

Dias depois, o havaiano Mark Foo morreria surfando em Maverick's. A onda, então ainda novidade no cenário do surfe, começava a se firmar como a mais temível do planeta.

Aqueles dias na praia de Santa Cruz, na Califórnia, ganharam espaço na mídia. $O$ Jornal New York Times, a rede de TV NBC e publicações locais destacaram os incidentes e as titânicas ondas e questionaram como o garoto Jay havia sobrevivido ao "wipeout for the millennium", segundo a capa da revista "Surfer".

Parece claro que existe um forte componente genético para as habilidades do californiano. A imensa maioria de surfistas jamais remaria naquele inferno gelado que para ele é como a Disneylândia. Mas ele sobreviveu para contar sua história. E não só pela sua cadeia de DNA. Treinou sério desde os 13 anos para desenvolver suas habilidades naturais, $e$, com certeza, a sorte também estava ao seu lado. Cada um tem e conta a história que merece. (Carlos Sarli, FSP-Esporte, 6/7/2000).

Numa passagem deste texto reencontramos a mesma ambigüidade de quantificação que apontei no título do texto anterior. Trata-se da possibilidade de escolher ou uma leitura genérica ("O californiano é geneticamente um hábil”, cp. "O 
sertanejo é antes de tudo um forte") ou uma leitura específica ("Moriarty é geneticamente hábil" ) para as expressões o californiano e ele que ocorrem na frase

"existe um forte componente genético para as habilidades do californiano. A imensa maioria de surfistas jamais remaria naquele inferno gelado que para ele é como a Disneylândia”.

Supondo que não haveria dificuldade em admitir a ambigüidade dessa frase, se ela aparecesse descontextualizada, tentemos verificar como essa ambigüidade se resolve, no processamento do texto. A primeira leitura que alguns leitores fazem de "o californiano" e "ele" (trata-se, é bom dizer, de leitores desinformados sobre Jay Moriarty e suas realizações surfísticas, e possivelmente de leitores desatentos) é a genérica. Essa leitura é favorecida pelo uso da forma verbal do presente simples, que conduz à interpretação generalizante. Todavia, na sequiência da leitura, diante da frase "Mas ele sobreviveu para contar sua história" esses mesmos leitores tendem a reavaliar que a melhor opção era entender "o californiano" [e as várias ocorrências de ele] como anafóricas de Jay Moriarty. O que impõe essa leitura é o uso do verbo no passado, incompatível com uma operação de generalização. $O$ fato de que "corrigimos", por assim dizer retrospectivamente, uma interpretação que até certa altura do texto parecia adequada indica, antes de mais nada, que toda expressão anafórica sofre condicionamentos igualmente fortes por parte do assim chamado "antecedente" e por parte da sentença em que está inserida. Mas indica também que os falantes sabem reconhecer que, em qualquer texto, funcionam determinadas "cadeias anafóricas". No caso analisado, trata-se de descartar a cadeia representada em (18) e ficar com a cadeia representada em (19):

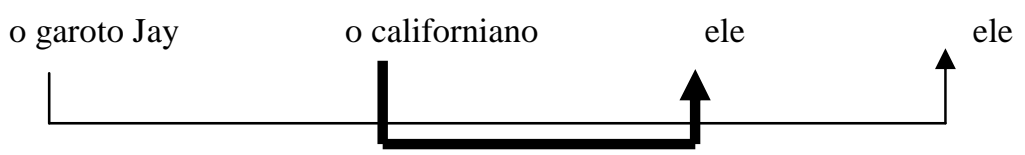

(18)

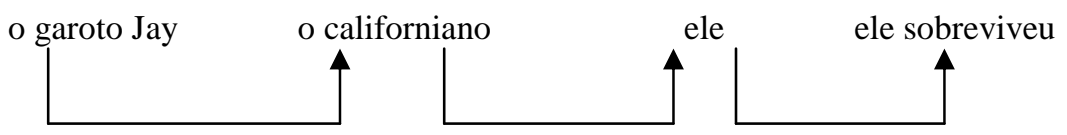

O fato de que os leitores escolhem (19) em vez de (18) parece mostrar que não é possível interpolar uma anáfora de sentido genérico em uma outra anáfora de sentido específico. Existem restrições desse tipo? É muito provável que sim, ou, melhor dizendo, é muito provável que uma interpolação desse tipo tenha um custo mais alto, no sentido de exigir um "trabalho lingüístico" bem mais complexo do que o observado nos dois textos comentados até aqui. Seja como for, fica caracterizada a necessidade de um estudo que distinga, de maneira mais geral, as interveniências que afetam a possibilidade de anáfora das interveniências que não a comprometem. Essa pesquisa terá de considerar a forma lingüística dos textos, mas terá também que considerar hipóteses sobre o funcionamento da memória e sobre o processamento cognitivo do material linguiístico, porque é possível que a anáfora resulte dificultada pela 
interpolação de segmentos mais longos ou que exigem um processamento cognitivo mais complexo.

3.2. O texto sobre a façanha de Jay Moriarty presta-se a uma outra observação sobre anáfora que leva a questionar uma das principais hipóteses de Vendler sobre termos singulares: a crença de que o artigo definido é sempre o correlato de uma operação explícita ou implícita de relativização.

Considere-se o uso que foi feito no texto da palavra prancha. Penso que a maioria dos leitores, mesmo aqueles que, como eu, pouco entendem de surfe, aceitarão como natural o fato de que, em sua única ocorrência no texto, essa palavra foi precedida por um artigo definido. Penso também que para qualquer falante de português, a leitura que se impõe para esse sintagma nominal definido é a singularizante. Se alguém perguntasse como chegamos a essa interpretação, uma boa resposta consistiria em dizer que, nesse ponto do texto, Moriarty fala na primeira pessoa, e que ele está falando de uma prancha em particular. E seria possível completar essa explicação dizendo que, mesmo que a prancha em questão tenha se perdido, todos sabem que os surfistas enfrentam as ondas munidos de uma prancha, o que nos faz pensar que, no dia 21/12/94, Moriarty devia certamente estar com uma. Essa explicação me parece suficiente, e de certo modo dispensa a necessidade de identificar no texto anterior a informação que, recuperada na forma de oração adjetiva, justificaria o aparecimento do artigo definido. $\mathrm{O}$ artigo entra naturalmente nessa ocorrência de a prancha (a única no texto) não porque poderíamos imaginar formulações como "a prancha que todo surfista usa ao surfar" (essa formulação nos obrigaria à proeza de achar a singularidade na generalidade) mas porque há um script da prática do surfe que é compartilhado inclusive por pessoas que nunca viram alguém praticar esse esporte ao vivo, e nesse script a prancha aparece como um ingrediente indispensável. Isso permite que a prancha funcione nesse texto como anafórico de um determinado episódio de surfar (quer dizer, de toda a situação evocada nas primeiras linhas), realizando o tipo de anáfora que Tesnière chamava de associativo.

Basta correr os olhos por qualquer texto escrito ou falado para nos convencermos de que as anáforas associativas são corriqueiras e permitem apresentar como conhecidos conteúdos que não foram previamente mencionados no texto, mas que podem ser associados a outros conteúdos que o foram. Aqui, a questão que se levanta é: há limites para as possibilidades de associação? Ao longo dos tempos, a noção de associação foi objeto de vários tratamentos célebres, alguns dos quais a caracterizam como uma operação perigosamente aberta, se não incontrolável. Um desses tratamentos é o de Hobbes, que pode ser resumido na afirmação de que a mente humana [pelo mecanismo de associação] vai de praticamente tudo a praticamente tudo. Ao contrário do que sugerem essas maneiras alarmistas de entender associação, a anáfora associativa faz uso de uma competência que nada tem de caótico, e que resulta, ao contrário, altamente estruturada. Se há limites para as associações, e elas resultam estruturadas, o problema consiste em explicitar que esquemas (lingüísticos? cognitivos?) garantem essa estruturação. Sobre esses esquemas há muito a dizer, e mais ainda a pesquisar. Aqui, 
ressalto apenas que alguns desses esquemas são amplamente compartilhados enquanto outros funcionam em comunidades cognitivas bem mais limitadas. Por exemplo, é provável que muitas pessoas que associam naturalmente surfe e prancha de surfe não saibam o que é um lip ou um maverick gigante. Para o leitor da página de esportes que conhece de maneira apenas imperfeita o script do surfe, o uso das palavras lip e maverick cria um problema de interpretação, que, no limite, pode levar ao fracasso de uma anáfora associativa ${ }^{6}$. Equívocos desse tipo ocorrem de fato, e podem ser comparados a outros equívocos que qualquer locutor corre o risco de cometer (por exemplo, quando usa os dêiticos apoiando-se em evidências não acessíveis ao interlocutor, ou quando, intencionalmente ou não, apresenta como dadas ou pressupostas informações que, de fato, são desconhecidas). A existência desses equívocos ajuda a lembrar uma característica que, embora seja mais evidente nesse tipo de anáforas - as associativas - se aplica em princípio a anáforas de qualquer tipo (assim como se aplica a qualquer operação de dêixis), a saber o fato de que seu funcionamento só pode ser compreendido quando se encara a atividade lingüística como uma atividade cooperativa.

3.3. O primeiro exemplo que analisarei em seguida provém de um texto sobre educação à distância, e diz respeito a um uso especial e pouco comum dos nomes próprios. Dadas as peculiaridades semânticas dos nomes próprios - em particular o fato de que eles são, na terminologia de Vendler, termos singulares primitivos (ou designadores rígidos, como também já se disse), não esperaríamos encontrá-lo em função anafórica: um nome nomeia o objeto a que se refere sem necessidade da mediação do texto. Há, contudo, ocorrências de nomes próprios que contrariam essa expectativa e que por isso mesmo merecem alguma atenção, ainda que um mínimo de análise leve à conclusão de que essas ocorrências são, precisamente, a exceção que confirma a regra.

Considere-se este texto, extraído de uma matéria do Correio Popular (Campinas) de 4 de agosto de 2000:

Gerson quer aprender contabilidade para melhorar de vida. Só tem o ginásio incompleto e estará numa cadeia em São Paulo pelos próximos dois anos por estelionato. Paulo é um médico que trabalha em Recife, e que ambiciona voltar para Catolé da Rocha, cidadezinha do alto sertão paraibano, onde nasceu, para fazer clínica rural. Mas teria de interromper o mestrado que está fazendo na universidade da capital. $O$ sonho dourado de Viviane, uma garota pobre do interior do Acre, é fazer rum curso de ecologia na Unicamp. Evidentemente, não tem dinheiro para isso. Albino, ao contrário, tem bastante dinheiro: é um super-executivo de um banco carioca, mas trabalha 12 horas por dia, e não encontra tempo para fazer o MBA de que tanto precisa para progredir na carreira.

Todos esses são exemplos reais de gente que pode ser ajudada pela educação à distância, ou EAD, a nova sigla "quente" de um conceito antigo, mas que está explodindo em crescimento no mundo todo, empurrada pelos ventos das novas tecnologias. A EAD representa uma oportunidade preciosa para todos os Gérsons, Paulos, Vivianes e Albinos da vida que desejam progredir por meio do estudo, mas que encontram barreiras intransponíveis no ensino convencional, seja pela impossibilidade de se deslocar, seja pela distância

\footnotetext{
${ }^{6}$ Boa parte da produção recente do prof. Luiz Antônio Marcuschi é dedicada a essa questão. Note-se que em vez da denominação "anáforas associativas", ele utiliza outra, mais atual e mais apropriada: "anáforas indiretas".
} 
geográfica, pelas limitações de tempo ou dinheiro... (Renato Sabbatini, "Aprendendo à distância”).

Há uma fortíssima razão para qualificar como anafórica a segunda ocorrência dos nomes próprios Gerson, Paulo, Viviane e Albino, aliás a mesma razão de sempre: para interpretar corretamente essas ocorrências, precisamos recorrer a informações presentes em outras passagens do mesmo texto, e os trechos do primeiro parágrafo em que esses mesmos nomes ocorrem pela primeira vez são, obviamente, os que interessam. É portanto constitutivo desse tipo de anáfora que os mesmos nomes sejam mantidos, assim como é inerente ao processo que esses nomes - provavelmente fictícios - sejam diferentes entre si, porque só assim eles poderiam evocar histórias de vida diferentes.

Mas, se as ocorrências do primeiro parágrafo nos fazem pensar em histórias de vida particulares, as do segundo transformam aquelas pessoas em protagonistas de casos exemplares ou, como poderíamos também dizer, convertem a situação que eles vivem em um papel que eles poderão compartilhar com outros intérpretes. Vista sob essa ótica, a "retomada" que ocorre no segundo parágrafo está a serviço de uma generalização, e os nomes ganham uma função que lembra a das variáveis lógicas (note-se que a interpretação do texto não se alteraria se, ao invés de nomes próprios de pessoas reais, o jornalista tivesse usado nomes vicários como "Fulano, Beltrano e Sicrano" ou mesmo letras do alfabeto ("o indivíduo A", "o indivíduo B", "o indivíduo C", etc.). Não é verdade, em suma, que toda ocorrência de um nome próprio funciona como um "termo singular primitivo". 7 A tendência é essa, mas é uma tendência que vários fatores contextuais podem reverter. Mais uma vez trata-se de especular sobre um funcionamento lingüístico do qual sabemos menos do que gostaríamos; deixo algumas dessas especulações para a seção 3.4.

Chegados a este ponto, convém que nos voltemos para um outro exemplo, construído à base de artigos indefinidos. Ele pode ser lido neste texto jornalístico, extraído da edição de 17/8/2000 do jornal O Estado de São Paulo.

Um centro cultural polivalente, com espaço privilegiado para as artes plásticas, mas que também terá ampla área dedicada ao teatro, ao cinema e à música, está prestes a surgir em pleno coração de São Paulo. O Instituto Tomie Ohtake, que está sendo erguido num quarteirão estratégico situado entre a rua Pedroso de Morais e a Avenida Faria Lima é uma produção familiar, que beneficiará uma população carente em espaços do gênero. A estréia está prevista paa meados do ano que vem.

Idealizado e coordenado por Ricardo Ohtake e projetado por Rui Ohtake, o centro pretende cunhar um novo modelo de espaço cultural, flexível e aberto às manifestações de vanguarda, sem deixar de lado a reflexão teórica. A idéia é trabalhar com o período que vai de 1952 - início da carreira de Tomie - até os dias de hoje.

Haverá espaço para um grande número de expressões artísticas, mas evidentemente será reservada uma área importante para as obras de Tomie, uma das mais renomadas

\footnotetext{
${ }^{7}$ Uma questão interessante é se os nomes próprios abdicam dessa condição quando passam a funcionar como variáveis, da forma descrita. O fato de que eles se fazem então acompanhar do nome próprio e de orações relativas restritivas parece indicar que sim. Provavelmente, expressões como "da vida" e "na vida", tais como as que ocorrem em "Os juízes Lalaus da vida andam soltos por aí", "Quem não quer ser um juiz Nicolau na vida?" estão se gramaticalizando como recursos para formar nomes comuns a partir de nomes próprios de pessoa.
} 
artistas plásticas brasileiras, e um dos raros nomes de nossa cultura a receber uma homenagem do gênero. Hélio Oiticica e Iberê Camargo (para quem está sendo construído um museu em Porto Alegre) têm instituições dedicadas à sua obra, mas ambas foram criadas longo tempo depois de eles morrerem.

Só foi possível tornar viável esse projeto graças à parceria de longa data entre Ruy e o laboratório Aché, proprietário do terreno e dos prédios que estão sendo construídos para locação de escritórios. Este é o oitavo projeto realizado pelo arquiteto para a empresa e foi essa proximidade que tornou possível reservar uma área importante (9,8 mil metros quadrados) para possibilitar um projeto longamente acalentado pelos irmãos Ohtake. Os cinco pavimentos do instituto serão cedidos em comodato por 30 anos. Victor Siaulys, um dos proprietários do Aché, foi colega de Ruy e chama Tomie de "minha mãe japonesa".

"A idéia tem uns oito anos, mas o instituto nasceu no papel em 1994", conta Ricardo, que será responsável pela gestão do Instituto. Atual secretário municipal do Verde, ele pretende criar um centro dinâmico e polivalente, capaz de refletir a cara de São Paulo. "Um lugar como esse não pode ser fatiado demais; não queremos que fique só de uma tribo."

... (Mara Hirszman, "Centro cultural terá a cara da cidade").

O que pretendo analisar nesse texto é a expressão que aparece grifada na penúltima linha. Meu entendimento é que essa expressão se interpreta anaforicamente, e a razão é, mais uma vez, que não conseguiríamos interpretá-la corretamente se pensássemos no que ela significa fora do texto. Penso que qualquer leitor entende que no texto todo se fala de um único Instituto Cultural, que é, nada mais nada menos que o Instituto Cultural Tomie Ohtake, em fase de construção quando a matéria de jornal foi escrita. Seria um equívoco imaginar que o filho da pintora estava então pensando na criação de um outro instituto cultural, mas é provavelmente a isso que nos levaria uma análise apressada da expressão destacada para análise, sobretudo se cairmos no equívoco de acreditar que um sintagma nominal indefinido sempre introduz um referente novo. Neste caso, a expressão indefinida não só não introduz um referente ainda não mencionado, mas, simplesmente, não é referencial. Podemos explicar a presença do artigo indefinido analisando a expressão como um predicativo, que nos diz o como da instituição a ser criada ("O Instituto Cultural T.O. será um centro dinâmico e polivalente, capaz de refletir a cara de São Paulo" / "Ricardo Othake imagina que o ICTO será um centro dinâmico e polivalente..." ); podemos também explicá-la mostrando que entre o "centro cultural dinâmico e polivalente" idealizado por Ricardo Ohtake e o espaço que está sendo concretamente construído com o apoio dos Laboratórios Aché há uma relação de contraparte ("Nos planos de Ricardo Ohtake, o ICTO é um centro cultural dinâmico e polivalente..." / "Ricardo Ohtake idealizou (o ICTO) como um centro cultural dinâmico e polivalente...” ). Em ambas as explicações (que a rigor não se excluem) dependemos do contexto para estabelecer que a interpretação referencial fica excluída: paradoxalmente, temos anáfora porque o contexto bloqueia a possibilidade de referência.

Meu último exemplo será de uma cadeia em que o primeiro termo é um predicativo e faz parte de uma fala citada "ipsis verbis". Segundo Vendler e Quine, essas seriam duas boas razões para esperar que essa "cadeia" não resulte num termo singular, e provavelmente é isso mesmo que acontece. Mas entre os dois termos há certamente anáfora (no sentido de que o segundo não faria sentido se não fosse o primeiro); por isso este exemplo traz à presente tentativa de distinguir as duas noções 
uma evidência particularmente convincente. $\mathrm{O}$ exemplo em questão foi retirado de um artigo de revista (mais provavelmente um número de Veja) dos anos 70:

As lições de Tarzan

Tarzan, o "Rei dos Macacos", estava desaparecido em alguma floresta da África desde que Hollywood se cansou de filmar suas aventuras. De origem nobre (seus pais eram aristocratas ingleses), inteligência notável (pois aprendeu a ler sozinho) e elogiável urbanidade no trato com pessoas e bichos, tendo inclusive desenvolvido rico relacionamento tanto com sua namorada Jane, quanto com sua macaca, Tarzan povoou os sonhos e as fantasias de várias gerações de crianças e por isso foi devidamente estudado pelos especialistas em histórias em quadrinhos e cinema. Assim, foi com um misto de surpresa e indignação que nove solitárias alunas de Ciências Sociais da Universidade Federal de Santa Catarina (que tem 8000 estudantes) receberam de sua professora Lélia Nunes a recomendação para que assistissem aos velhos filmes de Tarzan. Segundo a professora, estes filmes constituem "rica fonte de pesquisa para o estudo das populações primitivas".

As futuras sociólogas foram reclamar com a coordenadora Aurora Goulart e dela receberam um pito: se não assistissem às aulas, poderiam ser consideradas grevistas e punidas com o temível Decreto 477. Por fim, o chefe do Departamento de Sociologia da Universidade, professor Nereu do Valle Pereira, perguntou às reclamantes se por trás do seu protesto "não havia algum lance ideológico". Como todo sociólogo deve saber, havia. Pois, embora misteriosa e fascinante, a África dos filmes de Tarzan não existe: ela é formada pelos bosques e descampados da região de Los Angeles, por choupanas construídas no estúdio, e por habitantes de teatros e boates da cidade, onde tocam tambores, cantam e representam. Isso até o momento de pintarem o corpo e se transformarem na rica fonte mencionada pela professora.

Dois testes simples nos confirmam que a expressão na rica fonte mencionada pela professora é anafórica: 1) eliminando-se o primeiro parágrafo do texto, ou 2) eliminando-se nela mesma o adjunto mencionada pela professora, a expressão em questão se torna totalmente incompreensível. Aqui, a interpretação de uma expressão depende crucialmente da recuperação de um contexto de dizer (mais exatamente: um contexto de citação) que apareceu anteriormente no texto. $\mathrm{O}$ que a anáfora recupera é exatamente a alternância entre um contexto extensional e um contexto opaco, que segundo Vendler e Quine teria o efeito de bloquear a referência.

3.4. Estamos chegando ao final deste trabalho, e é tempo de verificar que conclusões ele autoriza, ainda que essas conclusões tenham um caráter provisório e, como eu já disse, especulativo / errático.

Ao longo deste artigo, alinhei argumentos que levam a entender que anáfora e correferência são fenômenos correlacionados mas distintos, e isso contraria, como já foi dito, uma tendência bastante arraigada, pela qual muitos lingüistas tendem a acreditar que o caso em que a anáfora exprime correferência é, possivelmente, o mais bem compreendido, aquele ao qual compensa voltar toda vez que a discussão do fenômeno se torna mais confusa e nossa intuição começa a negar fogo.

Com os exemplos que propus e comentei aqui, eu gostaria de ter criado no leitor a disposição para acreditar que o caso em que a anáfora veicula correferência não é nem o único possível nem o mais interessante ou instrutivo. É, na melhor das hipóteses, um caso limite, que nos impressiona por sua simplicidade, mas por isso mesmo transmite uma impressão de segurança até certo ponto enganosa. 
Os exemplos que analisei aqui levam, tanto quanto posso afirmar, a posições bem menos categóricas, em que é possível dimensionar mais corretamente a importância dos vários fatores:

a) a propósito do primeiro e do segundo textos vimos, por exemplo, que a possibilidade de optar entre uma interpretação singularizante e uma interpretação generalizante é uma ambigüidade que afeta muitas descrições definidas, e que geralmente se resolve no contexto. Vimos também que reconhecemos mais facilmente a existência de um vínculo anafórico entre dois sintagmas nominais quando ambos são singularizantes ou quando ambos são generalizantes. Não é impossível passar de uma interpretação singularizante a uma interpretação generalizante ou vice-versa (era esta uma das lições do texto sobre educação à distância) mas essa passagem - sempre possível - depende de uma elaboração específica. Proponho resumir tudo isso dizendo que a anáfora é sensível à quantificação. Não no sentido de haver condições automáticas e bloqueios intransponíveis, mas no sentido de que as relações entre anáfora e quantificação são objeto de uma organização relativamente complexa, a ser melhor compreendida. Em outros termos, as relações entre anáfora e quantificação são objeto de uma economia gramatical a ser estudada;

b) penso que cabe uma observação análoga para a relação entre anáfora e contextos transparentes ou opacos (para tratar dos fenômenos a que quero me referir, outros poderiam recorrer a noções como mundos possíveis ou espaços mentais, isso não é o importante). Nos casos mais simples, nosso discurso fica aderente ao mundo "real", e tenta dominá-lo mediante uma ontologia em que os objetos estão claramente separados e têm consistência espaço-temporal. Quando passamos a outras ontologias, a linguagem não nos abandona, ao contrário continua funcionando como um meio de acesso e orientação; mas ela precisa então dotar-se outros recursos, eventualmente mais complicados. Era essa a lição do texto sobre Tarzã.

c) finalmente, as observações que foi necessário fazer, "en cours de route", sobre o funcionamento da anáfora associativa acabaram por recolocar uma condição da anáfora que é, de certo modo, a mais geral de todas, e que aponta para o caráter essencialmente pragmático do fenômeno.

Todo locutor constrói sua fala a partir de uma avaliação da capacidade de interpretação do interlocutor, e da maneira como este reage às informações que são passadas pelo texto escrito ou falado. Em condições normais, ele tem o direito de supor que os mesmos objetos salientes na situação, os mesmos conhecimentos, e as mesmas informações estão presentes na atenção do interlocutor como na sua própria. Mas a comunicação não se faz apenas entre pessoas que têm o mesmo background cultural, que compartilham a mesma perspectiva sobre a situação ou que estão atentas ao mesmo tipo de dados. Assim, a decisão de apresentar certos conteúdos como recuperáveis é sempre uma questão de avaliação, e a avaliação pode ou não estar correta. Avaliações incorretas podem causar prejuízos mais ou menos sérios à comunicação, podem resultar em textos que serão percebidos como mais difíceis, podem exigir reformulações, comentários, digressões. Uma comunicação eficaz depende, em suma, de uma boa 
avaliação recíproca dos interlocutores, e isso nos faz reencontrar a propósito da anáfora aquele fator pragmático que é comum em lingüística, sendo a articulação tema/rema, a pressuposição e as implicaturas alguns de seus exemplos privilegiados.

Por tudo isso, penso que podemos dizer que a anáfora não é apenas um mecanismo de preservação de referentes, e nem mesmo um mecanismo de preservação de conteúdos. Tem pouco a ver com formas, e tem pouco a ver com mundo; ao contrário, tem muito a ver com o modo como armazenamos o mundo em algum "buffer cognitivo".

Se estou correto, a anáfora é um forte argumento para que, entre a linguagem e o mundo, queiramos situar uma interface que não é neutra, mas guarda as marcas cognitivas (culturais? psicológicas? sociais?) de nosso envolvimento com determinados grupos sociais que interpretam e conhecem, e que para isso confiam (ou agem como se confiassem) numa determinada organização do mundo. Essa é uma razão a mais para não querer fechar a questão da anáfora em torno da condição de correferência. Mas, como o leitor deve estar percebendo, aqui começa uma discussão que iria muito além dos objetivos deste artigo: mostrar alguns problemas de uma assimilação apenas aparentemente cômoda, que temos dificuldade em abandonar. 